\title{
VLIV POČTU VLÍCOVACÍCH BODŮ NA PŘESNOST MOBILNÍHO LASEROVÉHO SKENOVÁNÍ
}

\author{
INFLUENCE OF THE NUMBER OF CONTROL POINTS ON MOBILE \\ LASER SCANNING ACCURACY
}

Jakub Nosek $^{*}, 1$, Petr Kalvoda ${ }^{1}$, Michal Kuruc ${ }^{1}$, Tomáš Volařík ${ }^{1}$

"nosek.j@fce.vutbr.cz

${ }^{1}$ Vysoké učení technické v Brně, Fakulta stavební, Ústav geodézie, Veveří 331/95, Brno

\begin{abstract}
Abstrakt
Mobilní laserové skenování (MLS) je v současné době běžně využíváno v řadě geodetických aplikací, např. při mapování rozsáhlých oblastí. Tento článek se zaměřuje na vliv počtu vlícovacích bodů na výslednou přesnost bodových mračen MLS. MLS mračno bylo porovnáno s referenčními daty v podobě bodů testovacího pole určeného s vysokou přesností a referenčního mračna terestrického laserového skenování. Testování potvrdilo požadavky výrobce na maximální vzdálenost mezi vlícovacími body 100. Vlícování s vyšší hustotou (až $50 \mathrm{~m}$ ) umožňuje odstranit lokální deformace v mračnech MLS.
\end{abstract}

\section{Klíčová slova}

MMS, přesnost, laserové skenování, MLS

\begin{abstract}
Mobile laser scanning (MLS) is currently commonly used in a number of surveying applications, such as largearea mapping. This paper focuses on the effect of the number of control points on the resulting accuracy of MLS point clouds. The MLS cloud was compared with reference data in form of high-precision test point field and a terrestrial laser scanning reference cloud. Testing confirmed the manufacturer's requirements for the maximum spacing of control points $100 \mathrm{~m}$. Matching with a higher density (up to $50 \mathrm{~m}$ spacing) allows eliminating local deformations in MLS clouds.
\end{abstract}

Key words

MMS, accuracy, laser scanning, MLS

\section{1 ÚVOD}

Mobilní laserové skenování (MLS) je v současné době využíváno pro pořizování 3D mračen bodů v mnoha aplikacích, jako je mapování, katastr nemovitostí, 3D modelování měst a dopravní stavitelství [1], [2]. Geometrická přesnost výsledných produktů MLS je ovlivněna faktory, jako je přesnost vstupních dat, použitými algoritmy a hustotou vstupních a výstupních dat.

Přesnost MLS může být rozdělena na absolutní a relativní složku, které korespondují s polohovými a mapovacími subsystémy mobilního mapovacího systému (MMS). Polohový subsystém využívá data z Globálních navigačních satelitních systémů (GNSS), inerciální jednotky (IMU) a odometru (DMI). Výstupem polohového subsystému je trajektorie MMS. Tato trajektorie může být následně zpřesněna s využitím vhodného počtu vlícovacích bodů (VB). Mapovací subsystém zajištuje pořizování prostorových dat pomocí laserových skenerů a př́padně digitálních kamer. Přesná kalibrace obou subsystémů je jedním ze základních předpokladů pro zajištění přesnosti výsledných bodových mračen.

Návrhem metod pro zpřesňování výsledků MLS a hodnocením přesnosti procesu MLS se zabývalo několik autorů. Geometrická přesnost výsledných bodových mračen MLS může být zpřesněna využitím signalizovaných VB [3], které jsou identifikovány v bodových mračnech a pomocí vícenásobných průjezdů MMS [4]. Větší počet VB umožňuje dosahovat vyšší přesnosti na úkor vyšší časové a finanční náročnosti procesu. Nezávislé hodnocení chyb ve výsledných bodových mračnech lze provádět s využitím kontrolních bodů. Pro korektní hodnocení přesnosti bodového mračna $\mathrm{s}$ využitím kontrolních bodů je ale potřeba vytvořit testovací pole $\mathrm{s}$ dostatečným počtem kontrolních bodů. 
Druhou možností, jak kontrolovat geometrickou přesnost bodových mračen, je porovnání těchto mračen s přesným referenčním bodovým mračnem. Je nutné, aby přesnost referenčního bodového mračna byla významně vyšší než přesnost testovaného mračna. Vhodnou technologií pro tvorbu referenčního mračna je terestrické laserové skenování (TLS). Výhodou mračen TLS je jejich vysoká hustota a geometrická přesnost, díky které lze snáze hledat lokální deformace v mračnech MLS. Oproti zhotovení testovacího pole je ale tvorba referenčního TLS mračna technologicky a finančně náročná a referenční mračno má obvykle horší přesnost než jednotlivé kontrolní body.

Kaartien et al. [5] testovali 5 různých MMS na 1700 m dlouhém úseku silnice. Horizontální a vertikální přesnost MLS určovali na základě přirozeně signalizovaných kontrolních bodů, jako jsou rohy budov, rohy obrubníků a sloupy, extrahovaných z bodových MLS mračen. Vertikální přesnost výsledků z testovaných MMS byla lepší než $35 \mathrm{~mm}$ do vzdálenosti $35 \mathrm{~m}$ od trajektorie. Bodová mračna z nejlepšího testovaného MMS dosahovala vertikální přesnosti $\pm 1-2 \mathrm{~cm}$ a horizontální přesnosti $\pm 25 \mathrm{~mm}$.

Fryskowska and Wróblewski [6] využili referenční TLS bodové mračno pro testování přesnosti MMS dat. Testování bylo založeno na porovnání délek, jako jsou rozměry částí budov (stěn, střech) a také pomocí 395 kontrolních bodů. Celková horizontální a vertikální přesnost MLS mračna byla $\pm 60 \mathrm{~mm}$, respektive $\pm 42 \mathrm{~mm}$.

Tento článek se zaměřuje na posouzení vlivu počtu VB na přesnost bodových mračen MLS. Na rozdíl od ostatních článků bude $\mathrm{v}$ tomto článku pro stanovení přesnosti MLS použito velmi přesného testovacího pole (3D směrodatná odchylka jednotlivých bodů $\mathrm{S}_{3 \mathrm{D}}=2,0 \mathrm{~mm}$ ) a referenčního TLS bodového mračna.

\section{POPIS MMS RIEGL VMW-450}

MMS Rieg1 VMX-450 (základní technické charakteristiky uvedeny v Tab. 1) je modulární systém skládající se ze dvou laserových skenerů Riegl VQ-450, čtyř kamer VMY-450-CS6, panoramatické kamery POINT GREY Ladybug5, přijímače GNSS, IMU, odometru VMX-450-DMI a řídicí jednotky Riegl VMX-450-CU [7].

Absolutní polohová a úhlová přesnost deklarovaná výrobcem je splnitelná pouze za předpokladu dobrých podmínek pro měření GNSS (minimální výpadky signálu), při užití metody dvojitých diferencí (připojení na referenční stanici, případně sít' permanentních stanic GNSS) a využití dat z DMI. Hodnoty relativní polohové přesnosti v Tab. 1 odpovídají situaci, kdy je vzdálenost mezi sousedními VB maximálně $100 \mathrm{~m}$.

Tab. 1 Vybrané technické parametry MMS Rieg1 VMX-450 [7].

\begin{tabular}{ccc}
\hline \multirow{2}{*}{ Senzor } & Název parametru & Hodnota parametr \\
\hline VQ-450 & Princip měření & Měření tranzitního času \\
& Maximální frekvence pulsů & $1,1 \mathrm{MHz}(2 \times 550 \mathrm{kHz})$ \\
& Maximální rychlost otáček zrcadla & 400 otáček $/ \mathrm{s}$ \\
Vnější přesnost & Vnitřní přesnost & $5 \mathrm{~mm}(1 \times \sigma$ na vzdálenost $50 \mathrm{~m})$ \\
GNSS/IMU & Absolutní polohová př́esnost & $0,02-0,05 \mathrm{~m}(1 \times \sigma)$ \\
& Relativní polohová přesnost & $0,01 \mathrm{~m}(1 \times \sigma$ při vzdálenostech sousedních $\mathrm{VB}<100 \mathrm{~m})$ \\
& Úhlová přesnost (roll, pitch) & $0,005^{\circ}(1 \times \sigma)$ \\
& Úhlová př́esnost (yaw) & $0,015^{\circ}(1 \times \sigma)$ \\
\hline
\end{tabular}

\section{REFERENČNÍ DATA A ZPRACOVÁNÍ DAT MMS}

Pro testování přesnosti bylo využito testovací pole (TP) a referenční TLS mračno. TP bylo vytvořeno při řešení interního projektu Fakulty stavební VUT v Brně FAST-S-19-5704 „Geometrická přesnost mobilních mapovacích systémů“ v areálu výzkumného centra ADMAS. TP se skládá z celkem 214 bodů signalizovaných a stabilizovaných pomocí šachovnicových terčů. Horizontální terče (119) byly vyznačeny bílou barvou na asfaltových komunikacích (Obr. 1 vpravo). Vertikální terče (95) byly umístěny na dopravních značkách, budovách, betonových sloupech a dalších vhodných svislých předmětech. Obr. 1 zobrazuje ukázku vertikálního (vlevo) a horizontálního (vpravo) terče. Body TP byly zaměřeny pomocí totální stanice Trimble S8 HP a GNSS systémem Trimble R8s. Souřadnice bodů TP byly určeny vyrovnáním geodetické sítě metodou nejmenších čtverců kombinací terestrických a GNSS měření v systému ETRS89 (ETRF2000). Odhad přesnosti bodů TP lze vyjádřit pomocí 3D směrodatné odchylky $\mathrm{S}_{3 \mathrm{D}}= \pm 2.0 \mathrm{~mm}$. Referenční TLS mračno bylo získáno dvěma statickými laserovými skenerem Faro Focus3D X 130. Referenční TLS mračno bylo vlícováno na celkem 30 bodů TP. Odhad 
přesnosti TP a referenčního TLS mračna v podobě horizontálních $\left(\mathrm{s}_{\mathrm{HZ}}\right)$, vertikálních $\left(\mathrm{s}_{\mathrm{V}}\right)$ a $3 \mathrm{D}$ směrodatných odchylek (s 3 D $)$ je uvedena v Tab. 2.
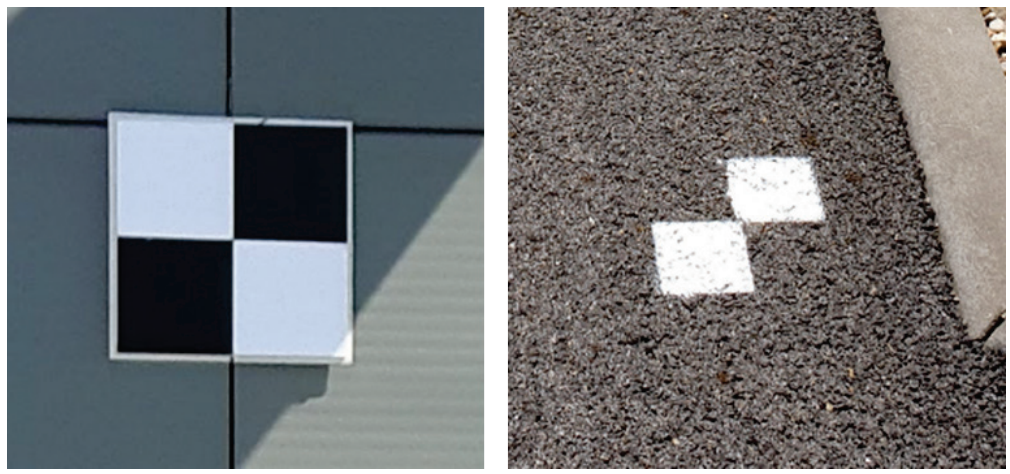

Obr. 1 Ukázka vertikálního (vlevo) a horizontálního terče (vpravo).

Tab. 2 Přesnost TP a referenčního TLS mračna.

\begin{tabular}{cccc}
\hline Varianta & SHz & Sv & S3D \\
\hline TP & $\pm 1,6 \mathrm{~mm}$ & $\pm 1,4 \mathrm{~mm}$ & $\pm 2,0 \mathrm{~mm}$ \\
Referenční TLS mračno & $\pm 7,4 \mathrm{~mm}$ & $\pm 4,1 \mathrm{~mm}$ & $\pm 8,5 \mathrm{~mm}$ \\
\hline
\end{tabular}

MLS data byla pořízena pomocí dvou protisměrných $600 \mathrm{~m}$ dlouhých průjezdů MMS při rychlosti $20 \mathrm{~km} / \mathrm{h}$. Skenovaný areál má rozměry přibližně 190×90 m v horizontálním směru. Výšková členitost areálu je přibližně 20 m. Trajektorie MMS byla vypočtena v programu Applanic POSPac s využitím kinematické GNSS metody s následným zpracováním. Trajektorie byla zpřesněna pomocí Kalmanova filtru kombinací dat z GNSS, IMU a odometru.

Zpracování MLS bodových mračen probíhalo v programu Riegl RiPROCESS. Zpracování v programu RiPROCESS se skládá z konverze dat, generování MLS bodových mračen a zpřesňování trajektorie. Nejprve byla MLS bodová mračna vypočtena na základě trajektorie z programu POSPac. Následně byly v MLS mračnech manuálně identifikovány body TP. Zpřesněná trajektorie byla vypočtena na základě vazeb mezi souřadnicemi bodů TP a souřadnicemi těchto bodů identifikovanými v MLS mračnech v modulu RiPRECISION. Výsledná bodová mračna ze dvou průjezdů MMS byla spojena v jedno a obsahují přibližně 247000000 bodů při průměrné hustotě $4 \mathrm{~mm}$. Filtrace a čištění MLS bodových mračen bylo vytvořeno v programu CloudCompare v2.11.

\section{METODOLOGIE URČOVÁNÍ PŘESNOSTI}

Určování přesnosti výsledných MLS mračen bylo založeno na porovnání mračen s referenčními daty. Testování přesnosti založené na TP využívalo rozdílů mezi referenčními souřadnicemi bodů TP a jejich souřadnicemi získanými z MLS bodových mračen. Určování přesnosti založené na referenčním TLS mračnu vycházelo z jeho porovnání s MLS bodových mračnem v programu CloudCompare v2.11. Rozdíly mezi mračny byly vypočteny pomocí funkce Cloud-to-Cloud Distance s lokálním modelováním metodou nejmenších čtverců. Horizontální přesnost MLS byla určována na fasádách, zatímco vertikální přesnost MLS byla určována na komunikacích. Pro testování přesnosti byly využívány horizontální, vertikální a 3D směrodatné odchylky (68\% konfidenční interval). Dále byla podle [8] bodová mračna testována na výskyt vybočujících (kritická hodnota $\alpha=5 \%)$ a odlehlých $(\alpha=$ $1 \%$ ) hodnot.

Globální přesnost bodových mračen na základě odchylek na bodech TP byla testována v několika variantách podle počtu a rozmístění $\mathrm{VB}$ (varianty $0 \mathrm{VB}, 1 \mathrm{VB}, 3 \mathrm{VB}, 4 \mathrm{VB}, 5 \mathrm{VB}, 6 \mathrm{VB}, 7 \mathrm{VB}, 10 \mathrm{VB}$ a $13 \mathrm{VB}$ ). 


\section{VÝSLEDKY}

Výsledky byly rozděleny do dvou částí podle zvoleného referenčního datasetu. Konfigurace VB v jednotlivých variantách podle počtu použitých VB znázorňuje Obr. 2. Odhad globální přesnosti bodových mračen MLS v podobě směrodatných odchylek vypočtených na základě odchylek na bodech TP jsou uvedeny v Tab. 3. Přesnost výsledků MLS roste společně se zvyšujícím se počtem VB až po variantu s 6 VB. To odpovídá požadavkům výrobce na maximální vzdálenost mezi VB 100 m.
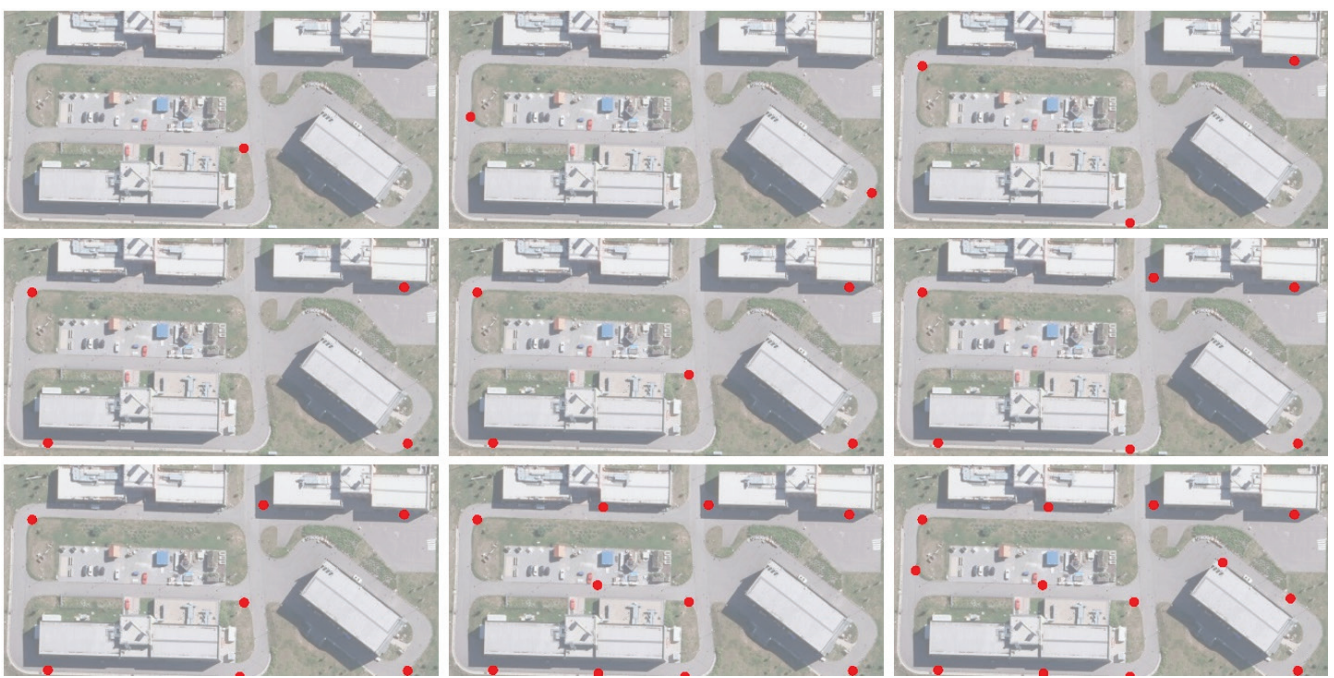

Obr. 2 Konfigurace variant s různým počtem VB.

Tab. 3 Přesnost variant odvozená z odchylek na kontrolních bodech.

\begin{tabular}{ccccc}
\hline Varianta & $\begin{array}{c}\text { Počet } \\
\text { kontrolních } \\
\text { bodů }\end{array}$ & SHz & Sv & S3D \\
\hline $\mathbf{0}$ VB & 204 & $\pm 36 \mathrm{~mm}$ & $\pm 127 \mathrm{~mm}$ & $\pm 130 \mathrm{~mm}$ \\
$\mathbf{1}$ VB & 203 & $\pm 26 \mathrm{~mm}$ & $\pm 42 \mathrm{~mm}$ & $\pm 59 \mathrm{~mm}$ \\
$\mathbf{2}$ VB & 202 & $\pm 32 \mathrm{~mm}$ & $\pm 43 \mathrm{~mm}$ & $\pm 64 \mathrm{~mm}$ \\
$\mathbf{3}$ VB & 201 & $\pm 18 \mathrm{~mm}$ & $\pm 33 \mathrm{~mm}$ & $\pm 49 \mathrm{~mm}$ \\
$\mathbf{4}$ VB & 200 & $\pm 17 \mathrm{~mm}$ & $\pm 59 \mathrm{~mm}$ & $\pm 59 \mathrm{~mm}$ \\
$\mathbf{5}$ VB & 199 & $\pm 20 \mathrm{~mm}$ & $\pm 37 \mathrm{~mm}$ & $\pm 51 \mathrm{~mm}$ \\
$\mathbf{6}$ VB & 198 & $\pm 16 \mathrm{~mm}$ & $\pm 30 \mathrm{~mm}$ & $\pm 48 \mathrm{~mm}$ \\
$\mathbf{7}$ VB & 197 & $\pm 16 \mathrm{~mm}$ & $\pm 30 \mathrm{~mm}$ & $\pm 46 \mathrm{~mm}$ \\
$\mathbf{1 0}$ VB & 194 & $\pm 15 \mathrm{~mm}$ & $\pm 32 \mathrm{~mm}$ & $\pm 46 \mathrm{~mm}$ \\
$\mathbf{1 3}$ VB & 191 & $\pm 14 \mathrm{~mm}$ & $\pm 34 \mathrm{~mm}$ & $\pm 43 \mathrm{~mm}$ \\
\hline
\end{tabular}

Horizontální a vertikální přesnost MLS vypočtená na základě porovnání s referenčním TLS mračnem je uvedena v Tab. 4. Relativní četnost vybočujících hodnot dosáhla $3 \%$. Až $2 \%$ hodnot v bodových mračnech MLS bylo vyhodnoceno jako odlehlých. Při vlícování na více než $6 \mathrm{VB}$ se globální přesnost zlepšuje pouze minimálně. Vlícování na 10 VB (průměrná vzdálenost mezi body $50 \mathrm{~m}$ ) nicméně významně redukuje lokální deformace v MLS mračnech. Obr. 3 a Obr. 4 znázorňují rozdíly mezi referenčním TLS mračněm a MLS mračny větší než $20 \mathrm{~mm}$ 
Tab. 4 Přesnost variant odvozená z referenčního TLS mračna.

\begin{tabular}{ccc}
\hline Varianta & SHz & Sv \\
\hline 6 VB & $\pm 14 \mathrm{~mm}$ & $\pm 7,7 \mathrm{~mm}$ \\
$\mathbf{7}$ VB & $\pm 14 \mathrm{~mm}$ & $\pm 7,4 \mathrm{~mm}$ \\
$\mathbf{1 0}$ VB & $\pm 6,1 \mathrm{~mm}$ & $\pm 7,7 \mathrm{~mm}$ \\
$\mathbf{1 3}$ VB & $\pm 5,9 \mathrm{~mm}$ & $\pm 7,9 \mathrm{~mm}$ \\
\hline
\end{tabular}

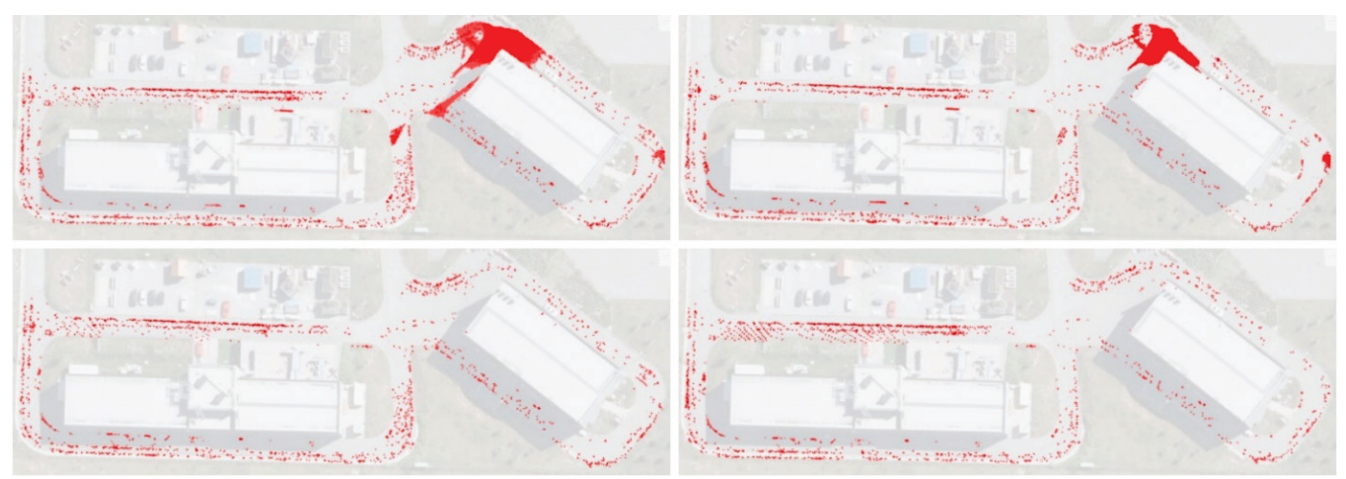

Obr. 3 Vertikální odchylky větší než 20 mm mračen z variant 6VB, 7VB (nahoře), 10VB, 13VB (dole) s referenčním TLS mračnem.
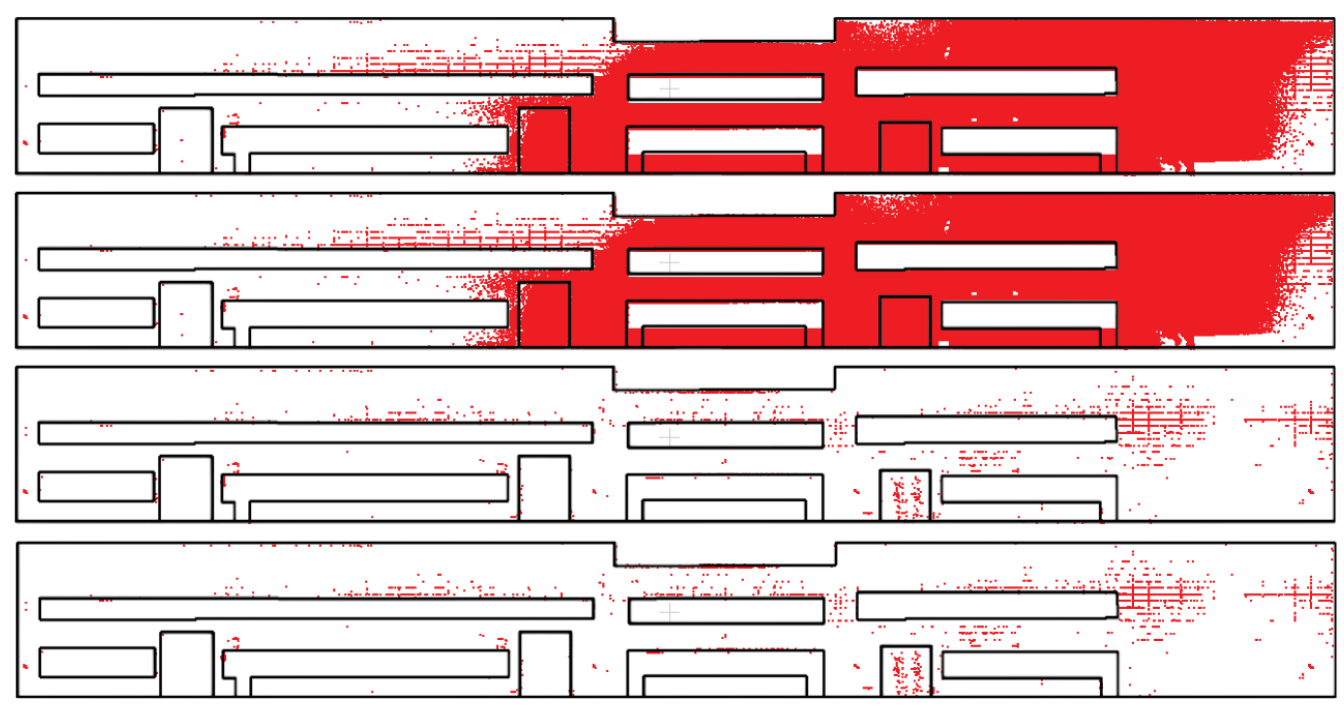

Obr. 4 Horizontální odchylky na vybrané fasádě větší než 20 mm mračen z variant 6VB (nahoře), 7VB, 10VB, 13VB (dole) s referenčním TLS mračnem.

\section{ZÁV̌̌R}

Použití vlícovacích bodů významně zvyšuje přesnost bodových mračen MLS, zejména v oblastech se špatnými podmínkami GNSS. Z tohoto důvodu jsme testovali vliv počtu VB na výslednou přesnost MLS mračen. Testování přesnosti bylo rozčleněno do dvou samostatných částí podle zvolených referenčních dat. Přesnost na základě referenčního TLS mračna byla samostatně určována pro horizontální složku souřadnic (na fasádách objektů) a vertikální složku (na komunikacích). 
Na základě testování přesnosti lze říci, že přesnost MLS mračen se významně zvyšuje až do varianty vlícování na 6 VB. Tato hodnota odpovídá požadavku výrobce na minimální vzdálenost mezi VB $100 \mathrm{~m}$. I přesto, že při přidávání dalších VB se globální přesnost MLS mračen zvyšuje pouze mírně, výsledky testování ukázaly, že vlícování na 10 VB (vzdálenost mezi body 50 m) může odstranit některé lokální deformace v mračnech MLS.

Přesnost dosažitelná při vlícování se vzdáleností mezi VB 100 m je dostatečná pro většinu běžných aplikací. Nicméně, lokální přesnost MLS mračen se zvyšuje až do průměrné vzdálenosti mezi VB 50 m.

\section{Poděkování}

Článek vznikl v rámci řešení projektu Specifického výzkumu VUT v Brně FAST-S-21-7484 Efektivita využití low-cost kamer v aplikacích blízké fotogrammetrie.

\section{Použité zdroje}

[1] Wang, Chen, Zhu, Liu, Li, Zheng. A Survey of Mobile Laser Scanning Applications and Key Techniques over Urban Areas. Remote Sensing. 2019 [cited 2021Oct.9];11(13). Available from: https://www.mdpi.com/2072-4292/11/13/1540

[2] Al-Bayari O. Mobile mapping systems in civil engineering projects (case studies). Applied Geomatics [Internet]. 2019;11(1):1-13. Available from: http://ink.springer.com/10.1007/s12518-018-0222-6

[3] Schaer P, Vallet J. TRAJECTORY ADJUSTMENT OF MOBILE LASER SCAN DATA IN GPS DENIED ENVIRONMENTS. ISPRS - International Archives of the Photogrammetry, Remote Sensing and Spatial Information Sciences [Internet]. 2016 [cited 2021Oct.9];XL-3/W4:61-64. Available from: http://www.int-arch-photogramm-remote-sens-spatial-inf-sci.net/XL-3W4/61/2016/isprs-archives-XL-3-W4-61-2016.pdf

[4] Nolan J, Eckels R, Evers M, Singh R, Olsen MJ. MULTI-PASS APPROACH FOR MOBILE TERRESTRIAL LASER SCANNING. ISPRS Annals of the Photogrammetry, Remote Sensing and Spatial Information Sciences [Internet]. 2015 [cited 2021Oct.9];II-3/W5:105-112. Available from: https://www.isprs-ann-photogramm-remote-sens-spatial-inf-sci.net/II-3-W5/105/2015/

[5] Kaartinen H, Hyyppä J, Kukko A, Jaakkola A, Hyyppä H. Benchmarking the Performance of Mobile Laser Scanning Systems Using a Permanent Test Field. Sensors . 2012;12(9):12814-12835. Available from: http://www.mdpi.com/1424-8220/12/9/12814

[6] Fryskowska A, Wróblewski P. Mobile Laser Scanning accuracy assessment for the purpose of base-map updating. Geodesy and Cartography. 2018;67(1):35-55.

[7] Riegl Laser Measurement Systems GmBH, RIEGL VMX-450: Compact Mobile Laser System, Data Sheet, 2015.

[8] Kalvoda P, Nosek J, Kuruc M, Volarik T, Kalvodova P. Accuracy Evaluation and Comparison of Mobile Laser Scanning and Mobile Photogrammetry Data. IOP Conference Series: Earth and Environmental Science. 2020;609. Available from: https://iopscience.iop.org/article/10.1088/1755$1315 / 609 / 1 / 012091$ 